\title{
Chemical Composition, Antioxidant and Antimicrobial Potential of Artichoke
}

\author{
Sobhy A. El Sohaimy* \\ Department of Food Technology, Arid land Cultivation Research, City of Scientific Research and Technological \\ Application (SRTA-City), Universities and Research Centers District, New Borgel Arab, 21923 Alexandria, Egypt
}

\begin{abstract}
Artichoke can be eaten as a fresh, canned or frozen vegetable for its health benefits due to the high content of polyphenols. The aim of this study is to elucidate the chemical composition, antioxidant and antimicrobial activity of globe artichoke (Cynara cardunculus L) and baby anzio artichoke (Cyrnara scolymus). The results of this investigation revealed that, the globe artichoke showed a moisture, protein and carbohydrate content higher than baby anzio. On the other hand the baby anzio showed a lipid content higher than globe artichoke. Baby anzio extract showed a higher phenolic compounds than glob artichoke extract. The baby anzio methanol extract showed the antioxidant activity higher than globe artichoke $\left(\mathrm{IC}_{50}\right.$ of baby anzio extract lower that $\mathrm{IC}_{50}$ of globe artichoke extract). At the same time the baby anizio extract exhibited more toxicity and inhibition zone diameter against 5 pathogenic bacterial strains than globe artichoke extract. This study confirmed that the two varieties of artichoke exhibited moderate functional properties like antioxidant and antimicrobial activity. Subsequently, baby anzio artichoke is more effective and powerful in antioxidant and antimicrobial activity.
\end{abstract}

Keywords: Anti-oxidant activity, anti-bacterial activity, artichoke, chemical composition, phenolic content.

\section{INTRODUCTION}

Artichoke belonging to the family Asteraceae is an herbaceous perennial crop [1]. Recently, a renewed and growing interest in the artichoke with a focus on new uses as a functional food has been observed [2]. Artichoke is widely cultivated for its large immature inflorescences, called capitula or heads. With edible fleshy leaves (bracts) and receptacle, which represent an important component of the Mediterranean diet, it is a rich source of bioactive phenolic compounds [3]. Artichoke can be eaten as a fresh, canned or frozen vegetable $[2,4]$. Since Roman times, this plant has been used in folk medicine for its health benefits which are mainly due to the high content of phenolic compounds and inulin $[5,2,6]$. Phenolic compounds are very important substances for human nutrition since they are involved in the prevention of cancer Cardiovascular diseases; osteoporosis, diabetes mellitus and neurodegenerative diseases [7]. In addition, leaves, rich in phenolic compounds [8], are used in herbal medicine and have been recognized since ancient times for their beneficial and therapeutic effects. Extracts from artichoke have been used for hepato-protection [9]. Among the common edible plants, artichoke is a rich source of dietary anti-oxidants; therefore it could be used in phytopharmaceutical applications $[2,10]$. The edible parts of

\footnotetext{
*Address correspondence to this author at the Department of Food Technology, Arid land Cultivation Research, City of Scientific Research and Technological Application (SRTA-City), Universities and Research Centers District, New Borgel Arab, 21923 Alexandria, Egypt;

Tel: +203-459-34-20; Fax: +203-459-34-23; Cell: +201001323230;

E-mail: elsohaimys@gmail.com
}

the artichoke plants are the large immature flowers, harvested in the early stages of their development, which represent about $30-40 \%$ of its fresh weight, depending on the variety and harvesting time. Since only the central portion of the capitula is consumed, the ratio of the edible fraction to the total biomass produced by the plant is very low, ranging from 15 to $20 \%$ of total biomass. This ratio further decreases, if the contribution to the total biomass represented by odd shoots that are often removed as part of common cultural procedures, is also considered [3]. The pharmacological properties of artichoke flower heads are well documented in several in-vivo and in-vitro studies for the treatment of hepato-biliary dysfunction, dyspeptic syndromes, gastric diseases, as well as for inhibition of cholesterol biosynthesis and low density lipoproteins (LDL) oxidative agents responsible for arteriosclerosis and coronary heart disease $[2,10]$. Artichoke leaf extracts decreased serum lipids, as well as hepatic and cardiac oxidative stress in rats fed on high cholesterol diet [11]. Wild artichoke extracts fed to aged rats seemed to exert cardioprotective effects [11]. The classic green globe artichoke variety (Cynara cardunculus L), sometimes called just the globe, has a buttery-tasting heart and bottom and an ample amount of meat at the base of the petals. This artichoke, which ranges in size from three to five inches in diameter and was traditionally cultivated as a perennial, was originally brought to California from Italy but is similar in shape and flavour to the French camus de bretagne, a summer choke grown in Brittany. Light red and only roughly one inch in diameter when fully grown, the purple baby anzio (Cynara scolymus) is a relative of the romanesco artichoke of the Lazio region of Italy. Like many baby artichokes, baby 
anzios can be cooked and eaten whole. The aim of this study is to explore the chemical composition of different tow verities of artichoke (Classic globe and baby anzio) and evaluate its potentiality as antioxidant and antimicrobial substance, to develop our knowledge about chemical and functional properties of artichoke.

\section{MATERIALS AND METHODS}

\section{Plant Materials}

The fresh artichoke Globe (Cynara cardunculus L) and Baby anzio (Cynara scolymus) plants were collected by us from the farm of the Ministry of Agriculture, Alexandria, Egypt and transferred to the laboratory under cooling condition in ice box with ice to keep the temperature under $10^{\circ} \mathrm{C}$ to avoid any lose of the active ingredients. The plant materials were washed with tap and distilled water, then stored in the polyethylene bags at $-80^{\circ} \mathrm{C}$ for further analysis [12]. All experiments were carried out in triplicate.

\section{Methanol Extract Preparation}

The crude methanol extract was prepared by maceration and crush of the frozen sample in a porcelain mortar $(50 \mathrm{~g}$ sample) with $1000 \mathrm{ml}$ methanol $(1: 20 \mathrm{w} / \mathrm{v})$. Mixture transferred to $2 \mathrm{~L}$ glass beaker, covered with aluminum foil or parafilm to prevent the evaporation of the solvent and stirred for $20 \mathrm{~min}$ at room temperature. The extract was filtered with filter paper (Wattman No.1) and evaporated to dryness under vacuum. The dried extract was stored at $\left(-80^{\circ} \mathrm{C}\right)$ for further analysis.

The Yield of extraction was calculated as follows:

$\%$ Yield $=\left(\mathrm{DW}_{\mathrm{e}} / \mathrm{DW}_{\mathrm{s}}\right) \times 100$

$\mathrm{DW}_{\mathrm{e}}$ is the weight of extract after evaporation of solvent, and $\mathrm{DW}_{\mathrm{s}}$ is the dry weight of sample.

\section{Moisture Content}

These methods were based on measuring the mass of water in a known mass of sample. The moisture content was determined by measuring the mass of food before and after the water is removed by drying according the standard method [13].

$\%$ Moisture $=\frac{M_{\text {ITTILL }}-M_{\text {DRID }}}{M_{\text {INTILL }}} \times 100$

Here, $M_{\text {INITIAL }}$ and $M_{\text {DRIED }}$ are the mass of the sample before and after drying, respectively.

\section{Total Lipid Content}

Total lipid was determined according to [14, 15]. Homogenized tissue ( $10 \mathrm{~g}$ ) was progressively added to small amounts of a chloroform/methanol 2:1 (v/v) mixture (up to $200 \mathrm{ml}$ ), with vigorous shaking, and then the extraction was carried out for further $2 \mathrm{~h}$, using an electromagnetic stirrer. The mixture was filtered, re-washed with fresh solvent and pressed. Fifty milliliters of $0.88 \%$ potassium chloride were added and the mixture was shaken. The aqueous layer was removed by aspiration and the washing procedure was repeated. Adding anhydrous sodium sulphate, then filtered again before the solvent was removed using a rotary evaporator, then dried the extract. The extract was then placed in a desiccators overnight and weighed

\section{Total Carbohydrate Content}

Chemical analysis for the determination of total carbohydrate was adapted from the phenol-Sulphuric acid method as described by [16]. One gram $(1 \mathrm{~g})$ of dried sample was mixed with $1 \mathrm{ml}$ phenol solution $(5 \% \mathrm{w} / \mathrm{v})$ followed by the addition of $5 \mathrm{ml}$ concentrated Sulphuric acid. The sample was left at room temperature for 30 min prior to measuring absorbance at $485 \mathrm{~nm}$ using a spectrophotometer (Ultrospec 2000, Amersham Pharmacia Biotech, Piscataway, NJ, USA). The total amount of carbohydrate was determined based on a standard calibration curve. The calibration curve was generated by serial concentrations of glucose $(0,25,50,75$, $100,125,150,175,200 \mu \mathrm{g} / \mathrm{ml})$. The concentration of sugar referred to original dried sample. All analyses using the phenol-Sulphuric acid method were performed in triplicate.

\section{Total Protein Content}

Determination of total nitrogen $(\mathrm{N})$ was conducted using the Kjeldahl procedure according to Nelson and Sommers method [17]. $1 \mathrm{~g}$ sample as weighed on Wattman No. 1 filter paper circles and filter paper was folded around and putted in Kjeldahl flask. One blank with the samples was run. 2 boiling chips were added to every flask and $30 \mathrm{ml}$ of Sulphuric acid were added to flask. The sample digested in the digestion Kjeldahl unit for $2 \mathrm{hrs}$ then removed from digestion unit and capped immediately with rubber stoppers and let to cool for $30 \mathrm{~min}$. For distillation $50 \mathrm{ml}$ of boric acid was added to $500 \mathrm{ml}$ flask for sample and blank and putt in the Kjeldahl distillation unit and the distillation was run out with sodium hydroxide. After distillation the titration was carried out with $0.1 \mathrm{~N}$ Sulphuric acid. The total nitrogen was calculated as follow

$\% \mathrm{~N}=(\mathrm{T}-\mathrm{B}) \times N \times 1.401$

where: $\mathrm{T}=\mathrm{mL}$ of sample titrated, $\mathrm{B}=\mathrm{mL}$ of blank titrated, $\mathrm{N}=$ acid normality

The $\%$ of protein $=\% \mathrm{~N} \times 6.25$

\section{Total Phenolic Compounds}

The total phenolic compounds assay was carried out using the Folin-Ciocalteu reagent, following the method of [18], and based on the reduction of a phosphowolframatephosphomolebdate complex by phenolics to blue reaction products. $1 \mathrm{mg}$ extract was dissolved in $1 \mathrm{ml}$ methanol and $500 \mu \mathrm{l}$ of dissolved sample was taken and added to $0.5 \mathrm{ml}$ of distilled water and $0.125 \mathrm{ml}$ of Folin-Ciocalteu reagent. The mixture was shaken and allowed to stand for 6 minutes before addition of $1.25 \mathrm{ml}$ of $7 \% \mathrm{Na}_{2} \mathrm{CO}_{3}$. The solution was adjusted with distilled water to a final volume of $3 \mathrm{ml}$ and mixed thoroughly. After incubation in the dark for $30 \mathrm{~min}$, the absorbance at $650 \mathrm{~nm}$ was read versus the prepared blank. A standard curve was plotted using different concentrations of Gallic acid (standard, 0-1000 $\mu \mathrm{g} / \mathrm{mL}$ ). Total phenolic content was estimated as $\mu \mathrm{g}$ Gallic acid equivalents (GAE)/mg of dry weight. 


\section{DPPH Radical Scavenging activity}

The Diphenyl Picrylhydrazyl (DPPH) Radical scavenging activity was estimated according to [19]. The dried plant extract was diluted in pure methanol at different concentrations ranging from 1-to $200-\mu \mathrm{g} / \mathrm{ml}$, and then $2 \mathrm{ml}$ were added to $0.5 \mathrm{ml}$ of a $0.2 \mathrm{mM}$ DPPH methanol solution. The mixture was shaken vigorously and left standing at room temperature for $30 \mathrm{~min}$ in the dark, and then the absorbance was measured at $517 \mathrm{~nm}$. For each dilution, the DPPH scavenging activity was calculated as $\left(\mathrm{A}_{0}-\mathrm{A}_{1}\right) / \mathrm{A}_{0} \times 100$, where $A_{0}$ is the absorbance of the control after $30 \mathrm{~min}$ incubation, and $A_{1}$ is the absorbance of sample after $30 \mathrm{~min}$ incubation. The antiradical activity was finally expressed as $\mathrm{IC}_{50}(\mu \mathrm{g} / \mathrm{ml})$, the extract concentration required to cause a $50 \%$ inhibition. A lower $\mathrm{IC}_{50}$ value corresponds to a higher anti-oxidant activity of the plant extract. All results compared with the same serial concentration of Ascorbic acid as known antioxidant agent.

\section{Anti-Microbial Activity}

The antimicrobial activities against 5 types of bacterial strains were obtained from Cairo-MIRCEN (Microbiological Resource Center) Faculty of Agriculture, Ain Shams University, (Proteus vulgaris ATCC6830, Escherichia coli 0143, Staphylococcus aureus 0006, Klebsiella pneumonia 8961 and Bacillus subtilis ATC6633) were studied. The determination of the minimal inhibitory concentration (MIC) was achieved by an adaption of the agar streak dilution method based on radial diffusion [20,21]. Suspensions of the microorganism were prepared to contain approximately $180 \mathrm{cfu} / \mathrm{ml}$ and the plates containing agar medium were incubated (100 ul spread on the surface). Different concentrations of extract were placed in the hole $(3 \mathrm{~mm}$ depth, $4 \mathrm{~mm}$ diameter) made in the center of the agar. Under the same conditions, different concentrations of Ampicillin were used as standard antibiotic. The MIC was considered to be the lowest concentration of the tested sample able to inhibit the growth of bacteria after $24 \mathrm{hr}$.

\section{Statistical Analysis}

Statistical analysis was carried out by Student T-Test program. All experiments were carried out in triplicate and the results were presented as mean $\pm \mathrm{SD}$ and $\mathrm{p} \leq 0.05$.

\section{RESULTS}

\section{Chemical Analysis}

The results of chemical analysis of artichoke are reported in Table 1. The results of moisture analysis showed that, Moisture content of globe artichoke was $(72.53 \pm 0.24)$ whereas the moisture content of baby anzio artichoke was $(65.24 \pm 0.15)$. The same trend was recorded with protein $(14.54 \pm 0.12 ; 12.39 \pm 0.18)$ and carbohydrate $(73.65 \pm 0.13$; $56.72 \pm 0.23)$ contents for globe artichoke and Baby anzio artichoke respectively. The total lipid of globe artichoke was $(02.36 \pm 0.07)$ and for baby anzio was $(03.78 \pm 0.14)$. From the obtained results we noted that the protein and carbohydrate content in globe artichoke significantly higher than baby anzio species but less in lipid content.

\section{Total Phenolic Compounds (TPC)}

Methanol extract of artichoke was prepared to determine the total phenolic content. The yield of extract obtained from twos species of dry artichoke (globe and baby anzio) materials were $(17.5 \% \pm 0.14 \mathrm{~g})$ for globe artichoke and $25.4 \% \pm 0.21$ for baby anzio as shown in Table 2 . The total phenolic content (TPC) in methanol extract was determined and the results revealed that, the TPC in globe artichoke and baby anzio species were $(30.70 \pm 1.87$ and $38.31 \pm 0.96 \mathrm{mg}$ GAE/g dry sample) respectively Table 2 . These results revealed that the baby anzio species contained TPC 1.25 times more than globe variety.

\section{DPPH-Free Radical-scavenging Activity}

DPPH-Free radical-scavenging activity assay was performed to determine antioxidant activity in the two examined varieties of artichoke methanol extract. The obtained results presented that, $\mathrm{IC}_{50}$ of globe artichoke extract was $75 \mathrm{ug} / \mathrm{ml}$ that gave $55.12 \pm 0.31$ percent inhibition, and $50 \mu \mathrm{g} / \mathrm{ml}$ for baby anzio gave the $49.52 \pm 0.16$ percent inhibition. Whereas; $\mathrm{IC}_{50}$ of ascorbic acid was less than $10 \mu \mathrm{g} / \mathrm{ml}$ was gave $58.41 \pm 0.16$ percent inhibition

Table 1. Chemical composition of artichoke. The values is the mean of three replicates of the sample \pm SD.

\begin{tabular}{|c|c|c|}
\hline General Analysis & Classic Glob & Baby Anzio \\
\hline \hline Total Moisture & $72.53 \pm 0.24$ & $65.24 \pm 0.15$ \\
\hline Total Protein & $14.54 \pm 0.12$ & $12.39 \pm 0.18$ \\
\hline Total Carbohydrate & $73.65 \pm 0.13$ & $56.72 \pm 0.23$ \\
\hline Total Lipid & $02.36 \pm 0.07$ & $03.78 \pm 0.14$ \\
\hline
\end{tabular}

Table 2. The yield and total phenolic compounds of artichoke.

\begin{tabular}{|c|c|c|}
\hline & Classic Globe & Baby Anzio \\
\hline \hline Yield & $17.5 \% \pm 0.14$ & $25.4 \pm 0.21 \%$ \\
\hline Total Phenolic compounds (mg GAE/g DW) & $30.70 \pm 1.87$ & $38.31 \pm 0.96$ \\
\hline
\end{tabular}


Table 3. The ascorbic acid as standard showed the higher antioxidant activities than the two verities of artichoke extract especially at low concentrations. The baby anzio species showed significant antioxidant activity higher than globe artichoke variety $(\mathrm{p} \leq 0.05)$.

\section{Anti-microbial Activity}

Results of the evaluation of antibacterial activity of methanol extract of artichoke showed a significant toxicity against Proteus vulgaris ATCC6830, Escherichia coli 0-143, Staphylococcus aureus 0006, Klebsiella pneumonia 8961 and Bacillus subtilis ATC6633. The MIC of methanol extract of globe artichoke verity was $100 \mathrm{mg} / \mathrm{ml}$ but for baby anzio verity was $75 \mathrm{mg} / \mathrm{ml}$. The artichoke methanol extract exhibited different inhibition zones against different bacterial strains as shown in Table 4 . The toxicity was higher against Escherichia coli $(2.76 \pm 0.21 \mathrm{~cm})$ and Proteus vulgaris $(2.63 \pm 0.15 \mathrm{~cm})$, than against Staphylococcus aureus (1.75 \pm 0.13$)$, Klebsiella pneumonia $(1.60 \pm 0.14)$ and Bacillus subtilis $(1.86 \pm 0.23)$ for globe artichoke extract. At the same time, the baby anzio species showed higher toxicity against Escherichia coli (3.54 \pm 0.25$)$, Proteus vulgaris $(3.42 \pm 0.32)$ and Staphylococcus aureus (3.45 \pm 0.19$)$ than that against Klebsiella pneumonia $(2.12 \pm 0.16)$ and Bacillus subtilis (2.67 \pm 0.26$)$. Methanol extract of baby anzio was more effective against five tested bacterial strains than globe artichoke extract $(\mathrm{p} \leq 0.05)$. The ampicillin as positive control showed a higher toxicity against five examined bacterial strains than both globe and baby anzio extracts Table 4 .

Processing the data, we found a significant positive correlation between the concentration of total phenolics in artichoke and antioxidant activity and antibacterial activity.

\section{DISCUSSION}

\section{Chemical Analysis}

The general chemical analysis revealed that, globe artichoke containing water more than baby anzio, this may attributed to the leaves of globe artichoke species thicker than of baby anzio species and retains a large amount of water in tissues. The protein and carbohydrate contents in globe variety are higher than baby anzio $(\mathrm{p} \leq 0.05)$; on the other hand, the lipid contents in baby anzio species are greater than globe species. These differences in the chemical composition of two species of artichoke might be attributed to the essence of the plant species and the growth conditions of the plant. These findings agree with Lutz et al. 2011 [22] in their study of chemical composition of mature artichoke. The results of chemical analysis revealed that; artichoke might be considered a good source for protein and carbohydrate.

Table 3. Antioxidant activity of artichoke $(p \leq 0.05)$. The values mentioned are the means of triplicates \pm SD.

\begin{tabular}{|c|c|c|c|}
\hline Conc. $\boldsymbol{\mu g} / \mathbf{m l}$ Inhibition & Globe Artichoke Extract & Baby Anzio Extract & Ascorbic Acid \\
\hline \hline 10 & $17.41 \pm 0.26$ & $20.34 \pm 0.23$ & $58.41 \pm 0.16$ \\
\hline 25 & $25.45 \pm 0.41$ & $36.23 \pm 0.21$ & $65.92 \pm 0.22$ \\
\hline 50 & $31.92 \pm 0.32$ & $49.52 \pm 0.16$ & $76.61 \pm 0.08$ \\
\hline 75 & $55.12 \pm 0.31$ & $62.19 \pm 0.19$ & $82.17 \pm 0.13$ \\
\hline 100 & $68.36 \pm 0.38$ & $74.86 \pm 0.21$ & $92.81 \pm 0.15$ \\
\hline 150 & $72.96 \pm 0.29$ & $79.78 \pm 0.14$ & $96.65 \pm 0.10$ \\
\hline 175 & $77.96 \pm 0.19$ & $87.43 \pm 0.17$ & $97.25 \pm 0.24$ \\
\hline
\end{tabular}

Table 4. Antibacterial activity of methanol extract of artichoke $(\mathrm{MIC}=100 \mathrm{mg} / \mathrm{ml}$ for goble artichoke, $\mathrm{MIC}=75 \mathrm{mg} / \mathrm{ml}$ for baby anxzio) $(\mathbf{p} \leq \mathbf{0 . 0 5}) . *(I Z D)=$ Inhibition zone diameter. $(-)=$ No inhibition zone detected. The values mentioned are the means of triplicates \pm SD.

\begin{tabular}{|c|c|c|c|c|}
\hline \multirow[t]{2}{*}{ Bacterial Strain } & \multicolumn{2}{|c|}{ Artichoke Methanol Extract $(I Z D * \mathrm{~cm})$} & \multirow[t]{2}{*}{ Ampicillin $(I Z D * c m)$} & \multirow[t]{2}{*}{ Methanol $(I Z D * c m)$} \\
\hline & Globe & Baby anzio & & \\
\hline Escherichia coli & $2.76 \pm 0.21$ & $3.54 \pm 0.25$ & $3.82 \pm 0.07$ & - \\
\hline Staphylococcus aureus & $1.75 \pm 0.13$ & $3.45 \pm 0.19$ & $2.56 \pm 0.03$ & - \\
\hline Bacillus subtilis & $1.86 \pm 0.23$ & $2.67 \pm 0.26$ & $3.65 \pm 0.07$ & - \\
\hline
\end{tabular}




\section{Total Phenolic Content}

The baby anzio variety gave an extraction yield more than globe one. The less yield of globe artichoke may be due to its high content of water. In the same time, the baby anzio gave TPC 1.25 times more than globe artichoke in methanol extraction. It may be due to the nature of variety and biosynthesis pathway and accumulation of the phenolic compounds in the plant.

\section{Antioxidant Activity}

The baby anzio species showed antioxidant activity higher than the globe species $(\mathrm{p} \leq 0.05)$. It may be due to the higher phenolic content of baby anzio than that in globe artichoke. These results agree with [23], who reported the aqueous methanol extract of artichoke contains a unique polyphenolic compounds having a strong antioxidant activities. These results show that, the artichoke containing a reasonable level of antioxidant ingredients that can play an important role in the potentiality of artichoke as a good nutrition source.

\section{Antimicrobial Activity}

The baby anzio species delivered a broad antimicrobial activity than the globe one $(\mathrm{p} \leq 0.05)$. In the same time both species showed reasonable antimicrobial activities against five pathogenic strains, (Proteus vulgaris ATCC6830, Escherichia coli 0-143, Staphylococcus aureus 0006, Klebsiella pneumonia 8961 and Bacillus subtilis ATC6633), but methanol extract showed the most toxicity against Escherichia coli 0-143 and Proteus vulgaris ATCC6830. On the other hand Staphylococcus aureus 0006 and Klebsiella pneumonia 8961 were the most resistant to methanol extract of artichoke. The mechanism of antibacterial may be due to diffusion of the active compounds from the site of application to the site of action where it can exert its toxicity $[24,25]$. This indicates that these extracts may be used as an antibacterial agent with reasonable safety margins to inhibit bacterial growth. The known anti-bacterial mechanism associated to each class of chemical to which the isolated compounds belong, may explain the antibacterial potency of the crude extract. The anti-bacterial activity of artichoke extract might be due to the presence of phenolic compound and the ability of phenolic compounds to bind to bacterial cell walls [26] and inhibit the microbial growth. The high effect of baby anzio extract may be attributed to the high content of phenolic compounds.

\section{CONCLUSION}

The aim of this study is to explore the chemical composition of globe (Cynara cardunculus L) and Baby anzio (Cyrnara scolymus) artichoke species and elucidate their antioxidant and antimicrobial activities to understand the nutritional potential of artichoke. Artichoke chemical analysis brings to light that artichoke contains a reasonable amount of essential nutritional ingredients like protein, carbohydrate and fibers that can play the key role of the metabolic process and has health benefits in human nutrition. Methanol extracts of globe and baby anzio artichoke showed a considerable antioxidant ingredients and antimicrobial activity. The baby anzio artichoke showed a higher antioxidant and antimicrobial activity than globe artichoke extract. This study revealed that there is a relationship between phenolic compounds and the potentiality of artichoke as antioxidant and antimicrobial. These findings revealed that, phenolic compounds are a key factor in the anti-oxidant activity of artichoke extract. Finally, we can conclude that; the artichoke plant since they may have a health benefit due to the high level of phenolic compounds and may be used to extract and formulate effective food supplements and additives.

\section{ACKNOWLEDGEMENT}

Department of Food Technology, Institute of Arid Land Cultivation Research; the City of Scientific Research and Technological Applications supported this study. The author declares no conflict of interest.

\section{REFERENCES}

[1] Bianco V. Present situation and future potential of artichoke in the Mediterranean basin. Acta Hort 2005; 681: 39-55.

[2] Lattanzio V, Paul AK, Vito L, Angela C. Globe artichoke: a functional food and source of nutraceutical ingredients. J Funct Foods 2009; 1: 131-44.

[3] Lattanzio V. Composizione valore nutritivo e terapeutico del carciofo, Informatore Agrario XXXVIII, 1982; 1: 18727-31.

[4] Efterpi C, Eleftherios B, Panagiota F. Nutritional and Functional Properties of Cynara Crops (Globe Artichoke and Cardoon) and Their Potential Applications: A Review. Int J App Sci Technol 2012; 2: 64-70.

[5] Sonnante G, Pignone D, Hammer K. The domestication of artichoke and cardoon: from Roman times to the genomic age. Ann Bot 2007; 100: 1095-1100.

[6] Pandino G, Lombardo S, Mauromicale G, Williamson G. Profile of polyphenols and phenolic acids in bracts and receptacles of globe artichoke (Cynara cardunculus var. scolymus) germplasm. J Food Compos Anal 2011a; 24: 148-53.

[7] Clifford M, Brown J. Dietary flavonoids and health, broadening the perspective. In: Andersen O \& Markham K Eds. Flavonoids: Chemistry, biochemistry and applications. CRC Press, Boca Raton: USA 2006.

[8] Fratianni F, Tucci M, De Palma M, Pepe R, Nazzaro F Polyphenolic composition in different parts of some cultivars of globe artichoke (Cynara cardunculus L. var. scolymus (L.) Fiori). Food Chem 2007; 104: 1282-86.

[9] Adzet Camarasa J, Carlos Laguna J. Hepatoprotective activity of polyphenolic compounds from Cynara scolymus against $\mathrm{CCl}_{4}$ toxicity in isolated rat hepatocytes. J Nat Prod 1987; 50: 612-7

[10] Ceccarelli N, Curadi M, Picciarelli P, Martelloni L, Sbrana C, Giovannetti M. Globe artichoke as functional food. Mediterranean J Nutr Metab 2010; 3: 197-201.

[11] Kucukgergin C, Aydin AF, Ozdemirler GO, Mehmetcik G, KocarToker N, Uysal M. Effect of artichoke leaf extract on hepatic and cardiac oxidative stress in rats fed on high cholesterol diet. Biol Trace Elem Res 2010; 135: 264-74.

[12] Falleh H, Riadh K, Kamel C, et al. Phenolic composition of Cynara cardunculus L. organs, and their biological activities. Comptes Rendus Biologies 2008; 331: 372-9.

[13] Horwitz W, Latimer GW. AOAC (2006). Official methods of analysis. In: (Eds.), Current through Revision $1,18^{\text {th }}$ ed. Association of Official Analytical Chemists, Gaithersburg: MD, USA, 2005.

[14] Folch J, Lees M, Stanley A. Simple method for the isolation and purification of total lipids from animal tissues. Jnl of Biol Chem 1957; 226: 497-509.

[15] Ways P, Hanan D J. Characterization and quantification of red cell lipids in normal man. Jnl Lipid Res 1964; 5: 318-28.

[16] Dubois M, Gilles JK, Hamilton PA, Rebers PA, Smith F. Colorimetric method for determination of sugars and related substances. Anal Chem 1956; 28: 350-6. 
[17] Nelson D W, Sommers L E. Determination of total nitrogen in plant material. Agron J 1973; 65:109-112.

[18] Dewanto V, Wu X, Adom KK, Liu RH. Thermal processing enhances the nutritional value of tomatoes by increasing total antioxidant activity. J Agric Food Chem 2002; 50: 3010-4.

[19] Hanato T, Kagawa H, Yasuhara T, Okuda T. Two new flavonoids and other constituents in licorice root: their relative astringency and radical scavenging effects. Chem Pharm Bull 1988; 36: 2090-7.

[20] Barbary O, El Sohaimy S, El Saadani M et al. Antioxidant, Antimicrobial and Anti-HCV Activities of Lignan Extracted from Flaxseed.Res J Agric Biol Sci 2010; 6: 247-56.

[21] Oboh IE, Akerele JO, Obasuyi O. Antimicrobial activity of the ethanol extract of the aerial parts of sida acuta burm.f. (malvaceae). Trop J Pharma Res 2007; 6: 809-13.

[22] Lutz M, Henriquez C, Escobar M. Chemical composition and antioxidant properties of mature and baby artichokes (Cynara scolymus L.), raw and cooked. J Food Compos Anal 2011; 24: 4954

[23] Mangfu W, James ES, Irma FA, Kan H, Qun YZ, Yaakov T. Analysis of antioxidative phenolic compounds in artichoke (Cynara scolymus L). J Agric Food Chem 2003; 51(3): 601-8.

[24] Laks P, Pruner M. Flavonoid biocides: structure/activity relations of flavonoid phytoalexin analogues. Phytochemistry 1989; 28: 8791.

[25] Hwu R, Tseng W, Gnabre J, Giza P, Huang R. Antiviral activities of methylated nordihydroguaiaretic acid. 1. Synthesis, structure identification, and inhibition of tat-regulated HIV transactivation. J Med Chem 1998; 41: 2994-3000.

[26] Cowan MM. Plant products as antimicrobial agents. Clin Microbiol Rev 1999; 12: 564-82.

Received: February 20, 2014

Revised: May 05, 2014

Accepted: May 06, 2014

(C) Sobhy A. El Sohaimy; Licensee Bentham Open.

This is an open access article licensed under the terms of the Creative Commons Attribution Non-Commercial License (http://creativecommons.org/licenses/by-nc/3.0/) which permits unrestricted, non-commercial use, distribution and reproduction in any medium, provided the work is properly cited. 